\title{
Evaluation of Patients Diagnosed with Brain Death in Paediatric Critical Care
}

\author{
(D) Muhterem Duyu', (1) Zeynep Karakaya2 \\ 1Medeniyet University, Göztepe Training and Research Hospital, Pediatric Intensive Care Unit, Clinic of Pediatrics, İstanbul, Turkey \\ 2Medeniyet University, Göztepe Training and Research Hospital, Clinic of Pediatrics, İstanbul, Turkey
}

\begin{abstract}
Aim: We aimed to investigate the rate of brain death (BD) determinations and organ donations in our tertiary pediatric intensive care unit (PICU), and to report the data on demographic pattern and supplementary descriptive data on the BD declarations.

Materials and Methods: Age and gender of the cases were recorded, and also clinical conditions causing BD were grouped and recorded under six headings including; traumatic brain injury (TBI), brain neoplasm, cardiac arrest, intracranial haemorrhage, central nervous system infection and other causes. The time from the PICU admission to the diagnosis of BD, the time from suspicion of BD to final diagnosis, duration of survival after diagnosis of $\mathrm{BD}$, confirmatory tests used, whether apnea test is performed, and inherent alterations (diabetes insipidus, hyperglycaemia, hypothermia) that occurred following diagnosis of BD were recorded. Organ donation rate, the name and number of organs harvested were determined.

Results: Twenty-three patients were diagnosed with BD. The mean age of the patients diagnosed with BD was $5.5 \pm 4.9$ years. The causative mechanism leading to BD was classified into six groups, out of which the most common diagnosis was TBI with a rate of $39.3 \%$. The meantime from PICU admission to BD diagnosis was $5.7 \pm 5.5$ days. The time period from suspicion of $B D$ to the final diagnosis was $1.6 \pm 0.7$ days and the meantime to develop cardiac arrest after diagnosis of BD was $13.1 \pm 21.6$ days in non-donor cases. The most commonly used confirmation test was brain computed tomography angiography with $82.6 \%$. The most common alteration that follow BD was diabetes insipidus (56.5\%). Four patients became organ donors (17.4\%).

Conclusion: Patients with severe TBI are the most likely candidates for BD declaration and suitable for organ donation for children in need. Early diagnosis and good donor care are of great importance, especially for paediatric patients waiting for organ transplants.

Keywords: Brain death, paediatric intensive care, organ donation
\end{abstract}

\section{Introduction}

Brain death $(B D)$ is a clinical condition characterized by the irreversible loss of all brain functions, including the brain stem (1). Patients diagnosed with BD can be accepted as organ donors by obtaining family consent for the transplantation $(1,2)$. In Turkey, the diagnosis of BD is made in accordance with the Turkish Law numbered 2,238 called "Harvesting, Storage, Grafting, and Transplantation of Organs and Tissues" (passed on June $3^{\text {rd }}$ 1979) with article 11 establishing the cause of death and saying 'In connection with the enforcement of this law, the case of medical death is established unanimously by a committee of 4 physicians consisting of one cardiologist, one neurologist, one neurosurgeon, and one anesthesiologist, according to the rules, methods, and practices equivalent to the level of science reached in the country'. Also, a subsequent 
amendment numbered 6,514 made according to the law which was adopted on the $2^{\text {nd }}$ of January 2014 established that BD must be diagnosed by a committee of two physicians; one neurologist or neurosurgeon and one anesthesiology and reanimation specialist or intensive care specialist $(3,4)$. Despite its acceptance as a legal mode of death in Turkey since 1979, progress in the awareness and declaration of BD has been slow and difficult in the pediatric population.

The number of patients waiting for organ transplantation due to organ failure is increasing in Turkey as in many other countries. The one and only treatment for these patients is organ transplantation (5). Therefore, the diagnosis of BD and the provision of good care for the donor have become more important for patients waiting for life saving organ transplantation. Approximately 25,000 patients are on a waiting list for organ transplantation in Turkey according to the current data (6).

The incidence of $\mathrm{BD}$ in the pediatric intensive care unit (PICU) is between $16 \%$ and $20 \%(7,8)$. In developed countries, acute brain injuries are the most common cause of $\mathrm{BD}$ in pediatric patients with traumatic brain injuries (TBI). TBI is the leading cause of death in children over 1 year of age (9-11). Diagnosis criteria for BD vary between countries due to some variables such as the requirement of certain tests and the number of physicians needed to establish the diagnosis. There have been a limited number of studies conducted on children regarding the diagnosis of $\mathrm{BD}$ and the subsequent process.

In this study; the demographic characteristics of pediatric patients diagnosed with $\mathrm{BD}$ in the last 4 years at the PICU of our hospital were examined retrospectively along with the confirmatory tests used in the diagnosis, the time to the occurrence of cardiac arrest after the diagnosis and the acceptance or rejection rates concerning organ donations of the families.

\section{Materials and Methods}

Twenty-three pediatric cases with a diagnosis of BD were retrospectively analyzed at Goztepe Training and Research Hospital in the tertiary level of PICU, between March 2015 and September 2019. This study was granted permission by the Ethical Board of Medeniyet University, Goztepe Training and Research Hospital (approval number: 2019/0328).

The BD diagnosis was made in accordance with the conditions outlined in the applicable law and the criteria specified in the guidelines $(3,12)$. An apnea test was performed after the establishment of normothermia, normotension, normovolemia and the value of arterial blood gas partial carbon dioxide pressure $\left(\mathrm{PaCO}_{2}\right)$ was between $35-45 \mathrm{mmHg}$ and partial oxygen pressure $\left(\mathrm{PaO}_{2}\right)$ was above $200 \mathrm{mmHg}$. Patients who did not meet these criteria or those who were hemodynamically unstable were not subjected to the apnea test. The result of the apnea test was considered positive in the absence of spontaneous breathing, despite the establishment of $\mathrm{PaCO}_{2} \geq 60 \mathrm{mmHg}$ and/or an increase by $20 \mathrm{mmHg}$ or more from the baseline. Brain computed tomography angiography (CTA) or transcranial doppler ultrasonography (dUSG) was performed as a confirmatory test in cases where an apnea test could not be performed or completed and in patients for whom it was not desirable to wait for a second neurological examination.

The age and gender of the patients were recorded, and also the clinical conditions leading to $\mathrm{BD}$ were grouped and recorded under six headings as follows; $\mathrm{TBI}$, brain neoplasm, cardiac arrest, intracranial hemorrhage (nontraumatic), central nervous system infection and other causes. In addition; archive files, computer records, and $\mathrm{BD}$ declaration forms were evaluated. The time from the PICU admission to the diagnosis of BD (admission - BD diagnosis time), the time from suspicion of $B D$ to final diagnosis (duration of diagnosis of $\mathrm{BD}$ ), duration of survival after diagnosis of BD, confirmatory tests used, whether or not an apnea test was performed, and inherent alterations [such as diabetes insipidus (polyuria, urine density $<1.005$, and serum $\mathrm{Na}$ level $>145 \mathrm{mEq} / \mathrm{dL}$ ), hyperglycemia (blood glucose $>180 \mathrm{mg} / \mathrm{dL})$, hypothermia $\left(<35^{\circ} \mathrm{C}\right)$ ] that occurred following the diagnosis of $\mathrm{BD}$ were recorded. The organ donation rate and the type and number of organs harvested were determined using data obtained from the department of organ transplantation coordination.

\section{Statistical Analyses}

The data were evaluated using SPSS version 18.0 (SPSS, Inc., Chicago, IL). Categorical variables were presented as frequency and percentage. Continuous variables were presented as mean \pm standard deviation [(minimum (min), maximum (max)].

\section{Results}

In the study period, a total of 1,738 admissions were recorded at the PICU with an overall mortality rate of $6.9 \%$ $(n=121)$. Within this period, there were 23 BD declarations. The frequency of $\mathrm{BD}$ was $1.3 \%$ in our patient population. The mean age of those children diagnosed with BD was $5.5 \pm 4.9$ (min: 0.4 , max: 15 years) years. From these, 65.2\% of patients $(n=15)$ were male and $34.8 \%(n=8)$ were female. The causative mechanism leading to BD was classified into six groups, out of which the most common diagnosis was TBI with a rate of $39.3 \%(n=9)$ (Table I). 
Among those patients with certified $\mathrm{BD}$, the meantime from PICU admission to BD diagnosis was $5.7 \pm 5.5$ days (min: 1, max: 24 days). The time period from suspicion of $\mathrm{BD}$ to the final diagnosis was $1.6 \pm 0.7$ days (min: 1 , max: 3 days) and the meantime to the occurrence of cardiac arrest after the diagnosis of BD was $13.1 \pm 21.6$ days in non-donor cases (min: 1, max: 95 days). An apnea test was applied in all cases for the proper diagnosis of BD. The test could not be completed due to hemodynamic and respiratory instabilities in four cases. Regardless of the outcome of apnea test, all patients underwent confirmatory testing (radiological imaging) to avoid unnecessary waiting for a second neurological examination. As a confirmation test, brain CTA was performed in 19 (82.6\%) of the patients, transcranial dUSG was performed in one patient (4.4\%) and both brain CTA and transcranial dUSG were performed in $3(13.0 \%)$ of the patients. Regarding certain alterations that follow BD, 34 alterations were observed in 23 patients. Among these alterations, $56.5 \%(n=13)$ developed $D I, 52.2 \%$ $(n=12)$ developed hypothermia, and 39.1\% $(n=9)$ developed hyperglycemia. Four patients became organ donors (17.4\%). From these four donors, 8 kidneys, 4 livers and 2 hearts were transplanted successfully. The detailed analyses of the 23 children with BD are shown in Table II.

\section{Discussion}

We assume that our findings may be considered acceptable as a representation of tertiary level PICUs in Turkey. We reported the incidence rate of BD to be $1.3 \%$ in our PICU. In the adult ICU settings, the reported incidence was $2.7 \%$ (13). Our observed BD rate seems to be similar to previous reports in the literature $(14,15)$.

In our study, it is reported that BD was more frequent in patients with severe TBI in the PICU. According to our study, $39.3 \%$ of BD cases occurred after trauma. However, in other PICUs, trauma was responsible for $8.6-73 \%$ of all BD cases in Turkey (15-17).

There are several past studies which evaluated the following; the duration of the diagnosis of $\mathrm{BD}$, the duration of survival after its diagnosis and the time from ICU admission to BD diagnosis. Sucu et al. (18) performed a study in pediatric patients and found that the mean duration of the diagnosis of BD was 2.1 \pm 1.1 days. In another study, this period was found to be $5.9 \pm 1.3$ days (17). The present study revealed that the duration of the diagnosis of $\mathrm{BD}$ was $1.6 \pm 0.7$ days. Meanwhile, Ozmert et al. (17) conducted a study and found that the mean duration of survival after diagnosis of BD was $6.9 \pm 7.4$ days with the longest surviving case reported to be 25 days. In another study, these periods were 6.8 days for patients less than 18 years old and 2.5 days for those greater than 18 years old (19). In our study, the duration of survival after the diagnosis of $\mathrm{BD}$ was found to be $13.1 \pm 21.6$ days, which is longer than

\begin{tabular}{|c|c|}
\hline Variables & Values \\
\hline Age (years), mean \pm SD (min-max) & $5.5 \pm 4.9(0.4-15)$ \\
\hline \multicolumn{2}{|l|}{ Gender, n (\%) } \\
\hline Male & $15(65.2)$ \\
\hline Female & $8(34.8)$ \\
\hline \multicolumn{2}{|l|}{ Causative Mechanisms, n (\%) } \\
\hline Traumatic brain injury & $9(39.3)$ \\
\hline Falls & $5(21.8)$ \\
\hline Motor vehicle accident & $4(17.5)$ \\
\hline Brain neoplasm & $3(13.0)$ \\
\hline Cardiac Arrest & $3(13.0)$ \\
\hline Asphyxia & $2(8.7)$ \\
\hline Trauma & $1(4.3)$ \\
\hline Intracranial haemorrhage & $3(13.0)$ \\
\hline Arteriovenous malformation & $2(8.7)$ \\
\hline Subarachnoid haemorrhage & $1(4.3)$ \\
\hline Central nervous system infection & $2(8.7)$ \\
\hline Other & $3(13.0)$ \\
\hline Hydrocephaly & $1(4.3)$ \\
\hline Shock and Multiple organ failure & $2(8.7)$ \\
\hline \multicolumn{2}{|l|}{ Confirmatory tests } \\
\hline Brain CTA & $19(82.6)$ \\
\hline Transcranial dUSC & $1(4.4)$ \\
\hline Brain CT angiography + Transcranial dUSC & $3(13.0)$ \\
\hline \multicolumn{2}{|l|}{ Alterations that follow brain death, $\mathrm{n}(\%)$} \\
\hline Diabetes insipidus & $13(56.5)$ \\
\hline Hypothermia & $12(52.2)$ \\
\hline Hyperglycaemia & $9(39.1)$ \\
\hline $\begin{array}{l}\text { aPICU admission - BD diagnosis time, mean } \pm \text { SD } \\
\text { (min-max) }\end{array}$ & $5.6 \pm 5.5(1-24)$ \\
\hline $\begin{array}{l}\text { 'Duration of diagnosis of } \mathrm{BD} \text { (days), mean } \pm \mathrm{SD} \\
\text { (min-max) }\end{array}$ & $1.6 \pm 0.7(1-3)$ \\
\hline $\begin{array}{l}\text { Duration of survival after diagnosis of BD (days), } \\
\text { mean } \pm \text { SD (min-max) }\end{array}$ & $13.1 \pm 21.6(1-95)$ \\
\hline Organ donation, n (\%) & $4(17.4)$ \\
\hline \multicolumn{2}{|c|}{$\begin{array}{l}\text { SD: Standard deviation, CTA: Computed tomography angiography, dUSC: } \\
\text { Doppler ultrasonoghraphy, PICU: Paediatric intensive care unit, BD: Brain } \\
\text { death, a: The time from the PICU admission to the diagnosis of BD, b: The time } \\
\text { from suspicion of BD to final diagnosis, Min: Minimum, Max: Maximum }\end{array}$} \\
\hline
\end{tabular}




\begin{tabular}{|c|c|c|c|c|c|c|c|c|c|}
\hline $\begin{array}{l}\text { Patient } \\
\text { no }\end{array}$ & $\begin{array}{c}\text { Age } \\
\text { (years) }\end{array}$ & Gender & Diagnosis & $\begin{array}{c}\text { Confirmatory } \\
\text { tests }\end{array}$ & $\begin{array}{c}\text { PICU } \\
\text { admission- } \\
\text { BD diagnosis } \\
\text { time (days) }\end{array}$ & $\begin{array}{c}\text { Duration } \\
\text { of } \\
\text { diagnosis } \\
\text { of BD } \\
\text { (days) }\end{array}$ & $\begin{array}{l}\text { Duration } \\
\text { of survival } \\
\text { after } \\
\text { diagnosis } \\
\text { of BD } \\
\text { (days) }\end{array}$ & Complications & $\begin{array}{l}\text { Apnoea } \\
\text { test }\end{array}$ \\
\hline 1 & 4.6 & Male & $\begin{array}{l}\text { Tuberculous } \\
\text { meningoencephalitis }\end{array}$ & CTA & 11 & 2 & 5 & $\begin{array}{l}\text { DI, hypothermia, } \\
\text { hyperglycaemia }\end{array}$ & Yes \\
\hline 2 & 7.8 & Male & $\begin{array}{l}\text { Diffuse intrinsic } \\
\text { pontine glioma }\end{array}$ & $\begin{array}{l}\text { Transcranial } \\
\text { dUSG }\end{array}$ & 1 & 1 & 1 & $\phi$ & Yes \\
\hline 3 & 14.9 & Female & $\begin{array}{l}\text { Arteriovenous } \\
\text { malformation }\end{array}$ & CTA & 2 & 1 & 9 & DI, hypothermia & Yes \\
\hline 4 & 9.2 & Male & $\begin{array}{l}\text { Diffuse intrinsic } \\
\text { pontine glioma }\end{array}$ & CTA & 10 & 3 & Donor & Hypothermia & Yes \\
\hline 5 & 9.3 & Male & $\begin{array}{l}\text { Non-traumatic } \\
\text { subarachnoid } \\
\text { haemorrhage }\end{array}$ & CTA & 11 & 2 & 2 & $\phi$ & No \\
\hline 6 & 4.9 & Male & $\begin{array}{l}\text { Cardiac arrest } \\
\text { (trauma) }\end{array}$ & CTA & 1 & 1 & 14 & DI, hypothermia & Yes \\
\hline 7 & 3 & Male & Fall & CTA & 2 & 1 & 2 & $\begin{array}{l}\text { DI, } \\
\text { hyperglycaemia }\end{array}$ & Yes \\
\hline 8 & 3 & Female & $\begin{array}{l}\text { Meningoencephalitis } \\
\text { (unidentified) }\end{array}$ & $\begin{array}{l}\text { Transcranial } \\
\text { dUSG CTA }\end{array}$ & 6 & 2 & 34 & $\begin{array}{l}\text { DI, hypothermia, } \\
\text { hyperglycaemia }\end{array}$ & Yes \\
\hline 9 & 0.8 & Female & Fall & $\begin{array}{l}\text { Transcranial } \\
\text { dUSG CTA }\end{array}$ & 9 & 3 & 17 & DI, hypothermia & Yes \\
\hline 10 & 0.6 & Male & $\begin{array}{l}\text { Motor vehicle } \\
\text { accident }\end{array}$ & $\begin{array}{l}\text { Transcranial } \\
\text { dUSG CTA }\end{array}$ & 3 & 1 & 1 & Hypothermia & Yes \\
\hline 11 & 12 & Female & $\begin{array}{l}\text { Motor vehicle } \\
\text { accident }\end{array}$ & CTA & 8 & 2 & Donor & $\phi$ & Yes \\
\hline 12 & 6.3 & Male & $\begin{array}{l}\text { Motor vehicle } \\
\text { accident }\end{array}$ & CTA & 14 & 2 & 22 & DI, Hypothermia & Yes \\
\hline 13 & 2.2 & Male & Fall & CTA & 1 & 1 & 1 & Hyperglycaemia & No \\
\hline 14 & 2.2 & Female & Shock & CTA & 4 & 2 & 95 & $\begin{array}{l}\text { DI, } \\
\text { hyperglycaemia }\end{array}$ & Yes \\
\hline 15 & 1.8 & Male & $\begin{array}{l}\text { Glioblastoma } \\
\text { multiforme }\end{array}$ & CTA & 4 & 2 & 3 & DI & Yes \\
\hline 16 & 1.5 & Female & Fall & CTA & 1 & 1 & 1 & $\phi$ & Yes \\
\hline 17 & 0.4 & Female & Shock & CTA & 5 & 2 & 3 & Hypothermia & No \\
\hline 18 & 14.4 & Male & $\begin{array}{l}\text { Ventricular shunt } \\
\text { malfunction }\end{array}$ & CTA & 24 & 3 & 11 & Hypothermia & Yes \\
\hline 19 & 1 & Female & Asphyxia & CTA & 3 & 1 & 4 & DI & No \\
\hline 20 & 15 & Male & $\begin{array}{l}\text { Arteriovenous } \\
\text { malformation }\end{array}$ & CTA & 3 & 1 & Donor & $\begin{array}{l}\text { DI, } \\
\text { hyperglycaemia }\end{array}$ & Yes \\
\hline 21 & 3 & Male & Asphyxia & CTA & 3 & 1 & Donor & $\begin{array}{l}\text { DI, } \\
\text { Hyperglycaemia }\end{array}$ & Yes \\
\hline 22 & 1.8 & Male & Fall & CTA & 2 & 1 & 9 & Hypothermia & Yes \\
\hline 23 & 6.8 & Male & $\begin{array}{l}\text { Motor vehicle } \\
\text { accident }\end{array}$ & CTA & 3 & 1 & 15 & $\begin{array}{l}\text { DI, hypothermia, } \\
\text { hyperglycaemia }\end{array}$ & Yes \\
\hline
\end{tabular}


what is seen in the literature. The reason for this longer period might be due to the fact that the longest surviving BD case in our study had 95 days of life after her diagnosis of $\mathrm{BD}$ and she is the longest surviving patient in the literature as far as we are aware.

In the physiopathology of BD, the irreversible loss of brain functions leads to the disruption of the central regulatory mechanisms. Hypothalamic pituitary adrenocortical regulation ceases. Antidiuretic hormone deficiency occurs in $65-90 \%$ of those patients with BD due to neurohypophyseal damage (20). Hypothermia is inevitable as the primary thermoregulation center is affected by hypothalamic injury, and vasoplegia-induced body heat loss occurs (21). In our study, DI was observed in $56.5 \%$ of BD cases, and hypothermia was observed in $52.2 \%$ of cases. In parallel, Bonetto et al. (8) found similar complication rates in their study.

Out of the 23 cases in our study, only 4 (17.4\%) families agreed to organ donation. Previous studies on pediatric BD patients from Turkey determined different donation rates varying from $0 \%$ to $27 \%$ (15-18). The organ donation rate was found to be $47 \%$ in 135 BD cases in a study from Canada which was based in four different PICU centers (22). In a multicenter study from Argentina, 147 cases of BD were evaluated and the organ donation rate was found to be $25 \%$ (8).

Golchet et al. (23) evaluated the factors affecting organ and tissue donation and reported that religious beliefs and to a lesser extent personal fears and concerns about the integrity of body parts have reduced organ donation rates. Similarly, we found that most of the families did not accept organ donation either because of religious beliefs or an unwillingness to disrupt body integrity. However, factors affecting organ donation rates are not limited to beliefs. In one study, the authors reported that the coordinator of organ transplantation who communicated with the families about organ donation had a significant effect (24). Another study which included 268 patients with a family approval rate of $78.4 \%$ for organ donation revealed that the organ donation approval rate increased with the increased frequency of meetings held by an organ transplantation coordinator with the family after the declaration of BD (25). As can be seen, family approval rates for organ donation vary greatly in different health centers. We believe that regular and effective interviews conducted by an experienced and trained organ transplantation coordinator from the beginning of the process will increase donation rates.
The final decision of BD diagnosis and management in the subsequent period vary according to the medical and legal regulations in different countries. The clinical evaluation must be verified by more than one physician in many countries as is also the case in Turkey. Until recently, approval of a neurologist, neurosurgeon, cardiologist and anesthesiologist were required for the declaration of $\mathrm{BD}$ as enforced by the law which was in force at that time. With an amendment in 2014, the approval of two physicians, one neurologist or neurosurgeon and one anesthesiologist and reanimation specialist or intensive care specialist is now sufficient for a diagnosis of BD (3). According to the law; in the presence of the clinical findings of $\mathrm{BD}$ and apnea test positivity, a second neurological examination should be performed at intervals varying according to age groups. The diagnosis of $\mathrm{BD}$ is established when clinical findings of $\mathrm{BD}$ persist in the second neurological examination which is conducted after a 48 hour period in infants less than 2 months old, after 24 hours in infants aged between 2 months to 1 year, after 12 hours in children above 1 year old and in adults, and after 24 hours in the presence of cardiopulmonary arrest or acute hypoxic-ischemic brain injury (3). If an apnea test cannot be performed for the diagnosis of $\mathrm{BD}$ or the established time for a second neurological examination is not appropriate, then confirmatory tests for cerebral blood flow (brain CTA, transcranial dUSG, magnetic resonance imaging angiography and brain scintigraphy) or Electrophysiological tests [electroencephalogram (EEG) and evoked potentials] should be performed (3). In our study, the apnea test was performed in all suspected BD cases. However, the test could not be completed in four patients due to hemodynamic and respiratory instabilities. In our study, confirmation tests (brain CTA, transcranial dUSG) were performed in all cases because of the requirement for patients who could not undergo the apnea test and also an unwillingness to wait for the second neurological examination in some cases. In our study, brain CTA was the most preferred confirmatory test (82.6\%). There were two main reasons to prefer this method; first of all, it was easy to transport patients to the imaging service/center which is located near to the PICU, secondly, it was difficult to find a neuroradiologist with sufficient experience in transcranial dUSG. In addition to brain CTA as a confirmatory test, there are some centers which prefer transcranial dUSC or EEG as well (8,16-19).

Livers, kidneys and hearts were the solid organs which were donated and successfully transplanted in our unit. Although in Turkey, the transplantation of livers and kidneys 
are seen frequently, cadaveric transplant rates are not as frequent as kidney and liver transplantations (26). A total of 27,146 organ transplantation procedures were carried out between January 2008 and December 2016, and only $27 \%$ of them were harvested from cadavers. (Data acquired from the Turkish Ministry of Health, Directorate for General Health Service, Organ, Tissue Transplantation and Dialysis Services Department). Raising awareness of BD with its early diagnosis, good donor care and awareness of the importance of organ donation in the society may increase organ transplantation rates from cadavers.

\section{Conclusion}

We concluded that patients with severe TBI are the most likely candidates for BD declaration and are suitable for organ donation to those children in need. Early diagnosis and good donor care are of great importance, especially for pediatric patients waiting for organ transplants. The organ transplantation rates from a cadaver are still far below the targeted rates in Turkey. Careful and planned public educational broadcasting campaigns with spiritual and religious leaders' speeches addressing the concerns of the relatives of patients may increase donation rates. In addition, we believe that donation rates may increase if family meetings are held by a trained and experienced coordinator.

\section{Ethics}

Ethics Committee Approval: This study was granted permission by the Ethical Board of Medeniyet University, Goztepe Training and Research Hospital (Approval number: 2019/0328).

Informed Consent: Patients diagnosed with BD can be accepted as organ donors by obtaining family consent for the transplantation

Peer-review: Externally peer-reviewed.

\section{Authorship Contributions}

Concept: M.D., Z.K., Design: M.D., Z.K., Data Collection or Processing: M.D., Z.K., Analysis or Interpretation: M.D., Z.K., Literature Search: M.D., Writing: M.D., Z.K.

Conflict of Interest: No conflict of interest was declared by the authors.

Financial Disclosure: The authors declared that this study received no financial support.

\section{References}

1. Drake M, Bernard A, Hessel E. Brain Death. Surg Clin North Am 2017; 97:1255-73.
2. 2238 sayılı Organ ve Doku Alınması, Saklanması, Aşılanması ve Nakli Hakkında Kanun, 03.06.1979 tarih ve 16655 sayılı Resmi Gazete.

3. 6514 sayılı Sağıı Bakanlığı ve Bağlı Kuruluşlarının Teşkilat ve Görevleri Hakkında Kanun Hükmünde Kararname İle Bazı Kanunlarda Değişiklik Yapılmasına Dair Kanun. 18.01.2014 tarih ve 28886 sayılı Resmi Gazete.

4. 6. Organ ve Doku Nakli Hizmetleri Yönetmeliği (Resmi Gazete Tarihi: 01.02.2012 Resmi Gazete Sayısı: 28191)

5. Abbud-Filho M, Ramalho H, Pires HS, Silveira JA. Attitudes and awareness regarding organ donation in the western region of Sao Paulo, Brazil. Transplant Proc 1995; 27:1835.

6. Available:https://organ.saglik.gov.tr/OTR/70lstatistik/ OrganNakillstatistikKamusal.aspx.

7. Burns I, Sellers D, Meyer E, et al. Epidemiology of Death in the PICU at Five U.S. Teaching Hospitals. Crit Care Med 2014; 42:2101-08.

8. Bonetto G, Taffarel P, Gamerman M, et al. Brain death and organ donation in Argentine pediatric intensive care units. A multicenter study. Arch Argent Pediatr 2018; 116:54-60.

9. Heron $M$, Sutton PD, Xu J, Ventura SJ, Strobino DM, Guyer B. Annual summary of vital statistics 2007. Pediatrics 2010; 125:415.

10. Keenan HT, Bratton SL. Epidemiology and outcomes of pediatric traumatic brain injury. Dev Neurosci 2006; 8:256-63.

11. Ashwal S. Clinical diagnosis and confirmatory tests of brain death in children. In: Wijdicks EFM (eds). Brain Death. Philadelphia, Lippincott Williams \&Willkins, 2001; 91-114.

12. Available from: https://www.saglik.gov.tr/TR,10528/organ-vedoku-nakli-hizmetleri-yonetmeligi.html.

13. Kıraklı C, Uçar ZZ, Anıl AB, Özbek I. The effect of shortening confirmed brain death diagnosis time on organ donation rates in the intensive care unit. Yoğun Bakım Derg 2011; 1:8-11.

14. Todres D. Brain Death. In: Slonim AD, Pollack MM (eds). Pediatric Critical Care Medicine. Philadelphia, Lippincott Williams \&Willkins, 2006; 790-95.

15. NY Öztürk, Fi Girgin, D Birtan, I Cinel. Exploring Brain Death at a Tertiary Pediatric Intensive Care Unit in Turkey; Incidence, Etiology and Organ Donation. J Pediatr Emerg Intensive Care Med 2016; 3:11-4.

16. MY Sarı, E Gül. Evaluation of Patients with Diagnosis of Brain Death. J Pediatr Emerg Intensive Care Med 2019; 6:156-9.

17. Özmert S, F Sever, G Ayar, MU Yazıcı, DK Öztaş. Brain Death and Organ Donation in Paediatric Intensive Care Unit. Turk J Anaesthesiol Reanim 2019; 47:55-61.

18. Sucu A, O Tolunay, $T$ Çelik, et al. Evaluation of Patients Diagnosed with Brain Death in Pediatric Critical Care. J Pediatr Emerg Intensive Care Med 2018; 5:59-63.

19. Karasu D, Yılmaz C, Karaduman I, Çınar YS, Büyükkoyuncu N. Beyin Ölümü Olgularının Retrospektif Analizi. Yoğun Bakım Derg 2015; 6:23-6.

20. Mascia L, Mastromauro I, Viberti S, Vincenzi M, Zanello M. Management to optimize organ procurement in brain dead donors. Minerva Anestesiol 2009; 75:125-33. 
21. Powers BM, van Hcereden PV. The physiological changes associated with brain death: current concepts and implieations for treatment of the brain death donor. Anesth Intensive Care 1995; 23:26-36.

22. Joffe AR, Shemie SD, Farrell C, Hutchison J, McCarthy-Tamblyn L. Brain Death in Canadian PICUs: Demographics, Timing, and Irreversibility. Pediatr Crit Care Medicine 2013; 14:1-9.

23. Golchet G, Carr J, Harris MG. Why don't we have enough cornea donors? A literature review and survey. Optometry 2000; 71:318-28.
24. Kıraklı C, Uçar ZZ, Anıl AB, Özbek I. Yoğun Bakım'da Beyin Ölümü Kesin Tanı Süresinin Kısalmasının Organ Bağışı Oranlarına Etkisi. Yoğun Bakım Derg 2011; 1:8-11.

25. Frutos MA, Blanca JM, Mansilla Jl, et al. Organ donation: a comparison of donating and nondo-nating families. Transplant Proc 2005; 37:1557-59.

26. Gomez MP, Arredondo E, Paez G, Manyalich M. International registry in organ donation and transplantation 2010. Transplant Proc 2012; 44:1592-97. 